\title{
Sistem Informasi Objek Wisata di Kabupaten Cianjur Berbasis Media Sosial
}

\author{
Sutono ${ }^{1}$ Kintan Meitasari ${ }^{2}$ \\ Program Studi Teknik Informatika \\ Fakultas Teknik Universitas Suryakancana \\ Sutono@unsur.ac.id kintanmeitasari3@gmail.com²
}

\begin{abstract}
The Design of Information Systems for Tourism Descriptions in Cianjur Regency Based on Social Media is an application that was built to promote tourism in Cianjur Regency, so that tourists by using this application can make it easier to find out tourist attractions, lodging, culinary and transportation routes to tourist locations that is in the Cianjur district.

The development of information technology that encourages the human need for fast and accurate information. As in the tourism sector, fast and accurate information is needed to make it easier for tourists to reach their destination. Cianjur Regency has many tourist attractions that are not widely known by the general public, especially the people of Cianjur itself, some only know the name of the tourist spot but do not know the location. This lack of information makes people visit tourist attractions that have been frequently visited and make other tourist attractions increasingly unrecognizable to many people.

With this application, it can help the community in getting information about tourist attractions in Cianjur. And can help the manager of tourist attractions in disseminating information about tourist attractions that are not widely known to the people of Cianjur Regency or from outside Cianjur Regency, such as Instagram and Facebook, this application works to measure the distance from where we are to our destination with an estimated cost that must be paid. issued, can know the culinary and lodging in the tourist location.

The system designed has the advantage of making it easier for tourists to receive information on natural tourism in Cianjur Regency, tourists can provide reviews of these tourist attractions, also between tourists can interact with each other through messages.
\end{abstract}

Keywords: Social Media, Tourism, Culinary .

\begin{abstract}
Abstrak
Perancangan Sistem Informasi Deskripsi Pariwisata di Kabupaten Cianjur Berbasis Media Sosial merupakan suatu aplikasi yang di bangun untuk mempromosikan pariwisata di kabupaten cianjur, sehingga para wisataman tersebut dengan menggunakan aplikasi ini dapat mempermudah dalam mengetahui tempat wisata, tempat penginapan, kuliner dan jalur transportasi menuju lokasi wisata yang ada di kabuparen cianjur tersebut.

Semakin berkembang teknologi informasi yang mendorong kebutuhan manusia akan informasi yang cepat dan akurat. Seperti dalam bidang pariwisata, informasi yang cepat dan akurat dibutuhkan agar mempermudah wisatawan untuk mencapai tujuan wisata yang akan dituju. Kabupaten Cianjur memiliki banyak tempat wisata yang belum banyak diketahui oleh masyarakat umum khususnya masyarakat Cianjur itu sendiri, ada yang hanya mengetahui nama dari tempat wisata tersebut tapi tidak mengetahui lokasinya. Kurangnya informasi tersebut membuat masyarakat mengunjungi tempat wisata yang sudah sering dikunjungi dan menjadikan tempat wisata yang lain semakin tidak dikenali banyak orang.

Dengan apliaski ini dapat membantu masyarakat dalam mendapatkan informasi mengenai tempat-tempat wisata yang ada di Cianjur. Serta dapat membantu pengelola tempat wisata dalam menyebarkan informasi mengenai tempat wisata yang belum banyak diketahui masyarakat Kabupaten Cianjur ataupun dari luar Kabupaten Cianjur, seperti hal nya Instagram dan facebook, aplikasi ini bekerja bisa mengukur jarak dari lokasi kita berada ke tempat tujuan dengan perkiraan biaya yang harus di keluarkan, bisa mengetahuai kuliner dan penginapan yang ada di tempat lokasi wisata tersebut.

Sistem yang dirancang mempunyai kelebihan untuk mempermudah wisatawan dalam menerima informasi wisata alam yang ada di Kabupaten Cianjur, wisatawan dapat memberikan ulasan terhadap tempat wisata tersebut, juga antar wisatawan dapat saling berinteraksi lewat pesan.
\end{abstract}

Kata kunci: Media Sosial,Wisata, kuliner . 


\section{PENDAHULUAN}

\section{A. Latar Belakang}

Menurut Undang-Undang No.10 Tahun 2009 tentang kepariwisataan, pariwisata adalah berbagai macam kegiatan wisata dan didukung berbagai fasilitas serta layanan yang disediakan oleh masyarakat, pengusaha, pemerintah pusat, dan pemerintah daerah. Sedangkan menurut World Tourism Organization, pariwisata didefenisikan sebagai rangkaian kegiatan perjalanan seseorang dan tinggal di luar daerah asalnya untuk kepentingan leisure (memanfaatkan waku luang dengan liburan), bisnis ataupun tujuan lainnya. Menurut Spillane [1], peranan pariwisata dalam pembangunan negara pada garis besarnya berintikan tiga segi, yaitu segi ekonomis (sumber devisa, pajak-pajak), segi sosial (penciptaan lapangan kerja), dan segi kebudayaan (memperkenalkan kebudayan nasional kepada wisatawan-wisatawan asing).Kabupaten Cianjur secara geografis berada di posisi $106^{\circ} 4-107^{\circ} 25$ bujur timur dan $6^{\circ} 21-7^{\circ} 32$ lintang selatan yang letaknya sebelah utara berbatasan dengan wilayah Kabupaten Bogor dan Kabupaten Purwakarta; sebelah timur berbatasan dengan wilayah Kabupaten Bandung dan Garut; sebelah selatan berbatasan dengan Samudera Indonesia; dan di sebelah barat berbatasan dengan wilayah Kabupaten Sukabumi. Letak strategis geografis Kabupaten Cianjur di persilangan jalur jalan regional Bandung-Bogor-Jakarta dan antara BandungSukabumi serta dukungan daya tarik wisatanya baik wisata alam, wisata budaya dan daya tarik wisata buatannya yang tersebar di berbagai wilayah menjadi salah satu tujuan destinasi yang menarik bagi masyarakat Jawa Barat, yang dibuktikan dengan prestasinya sebagai salah satu dari 10 (sepuluh) kabupaten/kota terfavorit seIndonesia pada ajang Indonesia Tourism Award di tahun 2010. Kabupaten Cianjur juga memiliki banyak tempat wisata yang belum banyak diketahui oleh masyarakat umum khususnya masyarakat Cianjur itu sendiri, ada yang hanya mengetahui nama dari tempat wisata tersebut tapi tidak mengetahui lokasi nya. Kurangnya informasi tersebut membuat masyarakat mengunjungi tempat wisata yang sudah sering dikunjungi dan menjadikan tempat wisata yang lain semakin tidak dikenali banyak orang. Juga kurangnya informasi mengenai rute angkutan umum yang sering kali menyita banyak waktu dan materi. Serta kurangnya informasi penginapan terdekat yang sangat dibutuhkan khususnya oleh wisatawan luar Kabupaten Cianjur. Dan kurangnya informasi kuliner serta budaya khas di sekitar objek wisata tersebut, yang dapat berguna bagi wisatawan lokal maupun luar. Berbagai hal yang sudah dilakuk $\mathrm{n}$ untuk mempromosikan pariwisata antara lain dengan menggunakan media televisi, radio, iklan, brosur, pameran dan yang terbaru adalah dengan menggunakan media sosial. Berbeda dengan media konvensional yang sudah bertahun-tahun lalu sering digunakan untuk promosi pariwisata, promosi dengan menggunakan media sosial masih tergolong baru dan tampaknya mulai mempunyai daya tarik tersendiri bagi pelaku-pelaku industri pariwisata untuk promosi melalui media sosial. Hal tersebut dapat dilihat dengan munculnya daerah pariwisata yang mulai memiliki akun- akun media sosial untuk pariwisatanya masing-masing. Tetapi akun-akun tersebut hanya fokus disatu tempat wisata saja, juga informasi yang ditampilkan belum memenuhi kebutuhan Wisatawan. Sehingga membuat Wisatwan tidak tertarik mengunjungi tempat wisata tersebut karena kurangnya informasi yang ditampilkan. Berdasarkan permasalahan yang diuraikan di atas, maka dibutuhkan sistem berbasis media social yang dapat membantu masyarakat dalam mendapatkan informasi mengenai tempat-tempat wisata yang ada di Cianjur. Serta dapat membantu para pengelola tempat wisata dalam menyebarkan informasi mengenai tempat wisata yang belum banyak diketahui masyarakat Kabupaten Cianjur ataupun dari luar Kabupaten Cianjur. Maka dalam jurnal ini kami akan mengulas tentang "SISTEM INFORMASI DESKRIPSI OBJEK WISATA DI KABUPATEN CIANJUR BERBASIS MEDIA SOSIAL".

Untuk melakukan kegiatan yang memberikan informasi tempat wisata kepada masyarakat di Kabupaten Cianjur khususnya maupun luar Kabupaten Cianjur.

\section{B. Rumusan Masalah}

Berdasarkan latar belakang masalah diatas, maka dapat diambil suatu rumusan masalah yang akan menjadi pembahasan dalam penelitian ini yaitu bagaimana membangun sebuah perancangan sistem informasi deskripsi objek wisata di Kabupaten Cianjur, yang dapat memberikan informasi tempat wisata, penginapan, budaya, kuliner dan jarak tempuh kepada masyarakat Kabupaten Cianjur khususnya maupun masyarakat luar Kabupaten Cianjur.

\section{Maksud Dan Tujuan}

a. Maksud

Maksud penelitian ini adalah membangun sebuah perancangan sistem informasi deskripsi objek wisata di Kabupaten Cianjur, yang dapat memberikan informasi tempat, penginapan, kuliner dan jarak tempuh wisata kepada masyarakat Kabupaten Cianjur maupun luar Kabupaten Cianjur.

b. Tujuan

Tujuan dari penelitian ini adalah sebagai berikut :

1. Dapat membantu wisatawan dalam mendapatkan informasi mengenai tempat-tempat wisata yang ada di Cianjur

2. Dapat membantu pengelola tempat wisata dalam menyebarkan informasi mengenai tempat wisata yang belum banyak diketahui masyarakat Kabupaten Cianjur ataupun dari luar Kabupaten Cianjur.

3. Dapat mempermudah wisatawan dalam mencari rute angkutan umum.

4. Dapat membantu wisatawan dalam mendapatkan informasi mengenai penginapan terdekat. 
5. Dapat membantu wisatawan lokal maupun luar dalam mendapatkan informasi makanan serta budaya khas Kabupaten Cianjur.

6. Antar wisatawan dapat saling berinteraksi dengan cara bertukar informasi mengenai tempat wisata yang ada di Kabupaten Cianjur baik berbentuk teks (komentar) maupun foto.

\section{Batasan Masalah}

Permasalahan yang akan dibahas yaitu:

1. Sistem ini hanya memberikan informasi tempat wisata, tidak dengan pembelian tiket, pembayaran tiket atau semacamnya.

2. Sistem ini memperoleh data-data mengenai tempat wisata yang ada di Kabupaten Cianjur hanya dari internet dan survey ke tempat wisata tersebut.

3. Sistem ini hanya memberikan informasi tempat wisata alam yang berada di Kabupaten Cianjur.

4. Sistem ini memberikan informasi rute angkutan umum hanya dari 3 Kota yaitu, Bandung, Bogor, dan Sukabumi.

5. Sistem ini dapat berinteraksi antar pengguna hanya melalui fitur ulasan, dan galeri.

6. Sistem ini dapat menggunakan fitur ulasan dan galeri hanya wisatawan yang memiliki akun saja.

7. Sistem ini hanya dapat memberi ulasan wisata dalam bentuk teks.

8. Sistem ini hanya memberikan informasi budaya dan kuliner khas daerah sekitar wisata.

9. Sistem ini hanya memberikan informasi penginapan yang paling dekat dengan wisata tersebut.

\section{METODE PENELITIAN}

A. Metodologi Penelitian

Metode penelitian yang digunakan adalah deskriptif, yaitu suatu metode dengan cara mengumpulkan data, mengolah, serta menganalisa data yang telah terkumpul kemudian ditarik kesimpulan dan diberkan saran-saran yang diperlukan. Metode yang digunakan adalah:

1. Pengumpulan Data

Pada proses pengumpulan data ini di lakukan dengan wawancara,survey, dan mengumpulkan Pustaka untuk membangun system. Rancangan yang dilakukan dalam proses pembuatan system ini dengan Analisa data seperti pada gambar di bawah ini

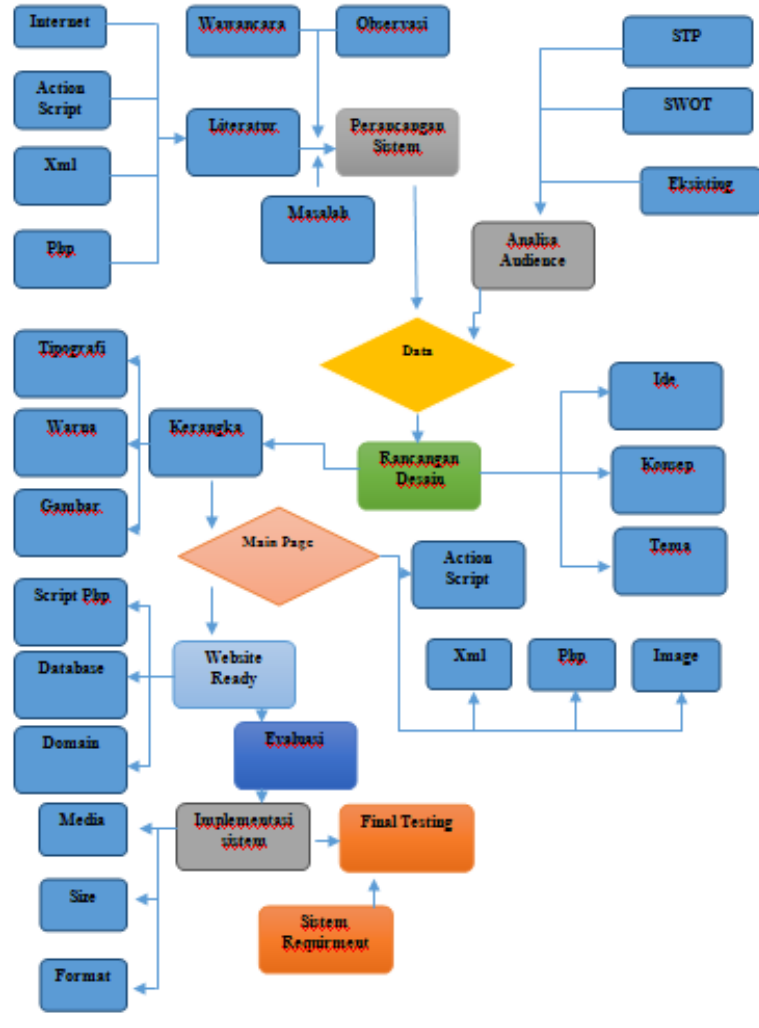

Gambar 1. Analisa Data

2. Rekayasa Perangkat Lunak

Metode rekaya perangkat lunak yang akan digunakan dalam penelitian tugas akhir ini adalah paradigma Waterfall, paradigm waterfall mempunyai tahapan sistem yang terstruktur.

Metode ini terdiri dari 5 tahap yaitu Communication, Planning, Modeling, Construction dan Deployment

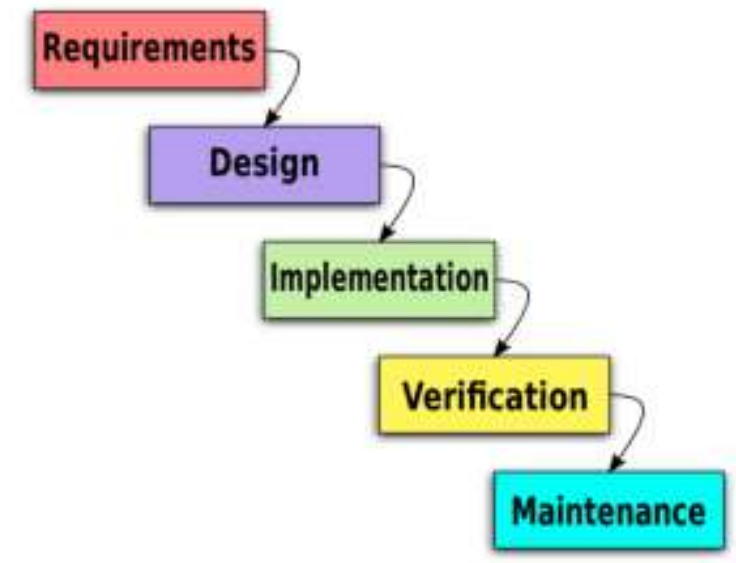

Gambar 2 . Metodologi Waterfall 


\section{B. Sistem Informasi}

Terdapat berbagai macam pengertian sistem informasi menurut beberapa ahli, diantaranya sebagai berikut :

1. Menurut Sutarman (Sutarman, 2012), "Sistem informasi adalah "Sistem dapat didefinisikan dengan mengumpulkan,

memperoses, menyimpan, menganalisis, menyebarkan informasi untuk tujuan tertentu. Seperti sistem lainnya, sebuah sistem informasi terdiri atas input (data, instruksi) dan output (laporan, kalkulasi)".

2. Menurut Mulyanto (Mulyanto, 2009), "Sistem informasi adalah suatu komponen yang terdiri dari manusia, teknologi informasi, dan prosedur kerja

yang memproses, menyimpan, menganalisis, dan menyebarkan informasi untuk mencapai suatu tujuan".

Dari pendapat di atas dapat disimpulkan bahwa sistem informasi merupakan gabungan dari manusia, hardware, software, jaringan komunikasi dan datayang saling berinteraksi untuk menyimpan, mengumpulkan, memproses, dan mendistribusikan informasi untuk mendukung pengambilan keputusan dalam suatu organisasi.

\section{Pariwisata}

Pengertian pariwisata menurut Norval

dalam Muljadi dan Nurhayati (Muljadi \& Nurhayati, 2002) adalah keseluruhan kegiatan yang berhubungan dengan masuk, tinggal, dan pergerakan penduduk asing di dalam atau di luar suatu negara, kota, atau wilayah tertentu.

Menurut definisi yang lebih luas yang dikemukakan oleh Kodhyat (Kodhyat, 1983) pariwisata adalah perjalanan dari satu tempat ke tempat lain bersifat sementara, dilakukan perorangan atau kelompok, sebagai usaha mencari keseimbangan dan kebahagiaan dengan lingkungan hidup dalam dimensi sosial, budaya, alam, dan ilmu. Selanjutnya menurut Musanef ((Drs.), 1995), mengartikan

pariwisata sebagai suatu perjalanan yang dilaksanakan untuk sementara waktu, yang dilakukan dari satu tempat ke tempat yang lain untuk menikmati perjalanan bertamasya dan berekreasi.

Menurut Yoeti (Yoeti, n.d., 2008) pariwisata harus memenuhi empat kriteria di bawah ini, yaitu:

1. Perjalanan dilakukan dari suatu tempat ke tempat lain, perjalanan dilakukan di luar tempat kediaman di mana orang itu biasanya tinggal;

2. Tujuan perjalanan dilakukan semata-mata untuk bersenang-senang, tanpa mencari nafkah di negara, kota atau DTW yang dikunjungi.

3. Uang yang dibelanjakan wisatawan tersebut dibawa dari negara asalnya, di mana dia bisa tinggal atau berdiam, dan bukan diperoleh karena hasil usaha selama dalam perjalanan wisata yang dilakukan; dan

4. Perjalanan dilakukan minimal 24 jam atau lebih.
Dalam pengertian kepariwisataan terdapat empat faktor yang harus ada dalam batasan suatu definisi pariwisata. Faktor-faktor tersebut adalah perjalanan itu dilakukan dari satu tempat ke tempat lain, perjalanan itu harus dikaitkan dengan orang-orang yang melakukan perjalanan wisata semata-mata sebagai pengunjung tempat wisata tersebut.

\section{Media Sosial}

Merujuk dari McGraw Hill Dictionary (Lapedes, 1974), menyatakan Media sosial adalah sarana yang digunakan oleh orang-orang untuk berinteraksi satu sama lain dengan cara menciptakan, berbagi, serta bertukar informasi dan gagasan dalam sebuah jaringan dan komunitas virtual.

Menurut Thoyibie (Thoyibie, 2010), media sosial adalah konten berisi informasi, yang dibuat oleh orang yang memanfaatkan teknologi penerbitan, sangat mudah diakses dan dimaksudkan untuk memfasilitasi komunikasi, pengaruh dan interaksi dengan sesama dan dengan khalayak umum. Dewasa ini, praktek pemasaran melalui media sosial mulai berkembang dan digunakan sebagai alat pemasaran produk mempromosikan merek dan brand suatu perusahaan.

Varinder Taprial dan Priya Kanwar (Taprial \& Kanwar, 2012), juga mengemukakan bahwa media sosial adalah media yang digunakan oleh individu agar menjadi sosial, atau menjadi sosial secara daring dengan cara berbagi isi, berita, foto dan lain-lain dengan orang lain.

Dari uraian diatas dapat disimpukan bahwa media social adalah media yang diberdayakan oleh individu maupun korporasi untuk berbagi informasi maupun berineterasi secara langsung dengan pengguna lainnya dan dapat terkoneksi dengan dengan media lainnya.

Yulianita, Neni \& Ninok Leksono. (Yulianita \& Leksono, 2011), mengemukakan bahwa media sosial merupakan pemahaman dari kelompok jenis komunikasi media online, yang meliputi karakter-karakter sebagai berikut:

1. Adanya Partisipasi: Media sosial mendorong umpan balik dan memberiakan kontribusi agar setiap orang tertarik.

2. Adanya Keterbukaan: media sosial terbuka untuk memberikan umpan balik dan ikut berpartisipasi, serta mendorong untuk melakukan pilihan, memberikan komentar dan sharing informasi.

\section{HASIL PENELITIAN}

Output dari hasil penelitian ini adalah berupa pencangan system dan design yang di butuhkan dalam membuat system Perancangan Sistem Informasi Deskripsi Pariwisata di Kabupaten Cianjur Berbasis Media Sosial.

\section{A. Use Case Diagram}

Use Case Diagram mendeskripsikan kelakuan sistem dari sudut pandang pengguna, berguna untuk membantu memahami kebutuhan. Berikut use case diagram dari Perancangan Sistem Informasi Deskripsi Pariwisata di 
Kabupaten Cianjur Berbasis Media Sosial terdapat pada Gambar 3

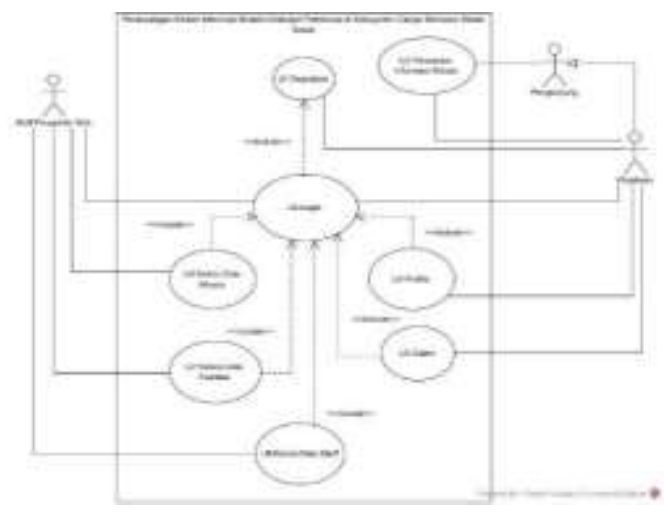

Gambar 3

Use Case Diagram Perancangan Sistem Informasi Deskripsi Pariwisata di Kabupaten Cianjur Berbasis Media Sosial

\section{B. Class Diagram}

Class Diagram adalah sebuah spesifikasi yang jika diinstansiasi akan menghasilkan sebuah objek dan merupakan inti dari pengembangan dan desain berorientasi objek. Class Diagram PerancanganSistem Informasi Deskripsi Pariwisata di kabupaten Cianjur Berbasis Media Sosial terdapat pada Gambar 4:

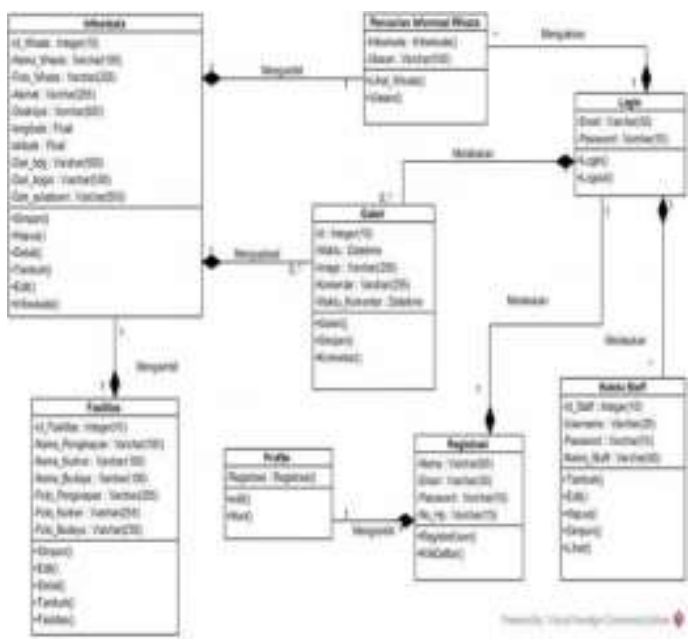

Gambar 4

Class Diagram Perancangan Sistem Informasi Deskripsi Pariwisata di Kabupaten Cianjur Berbasis Media Sosial

\section{Perancangan Sistem}

Pada perancangan sistem ini akan di bahas tentang perancangan antar muka pada perangkat lunak yang akan di bangun yang meliputi perancangan antarbuka dari sisi aplikasi android sebagai front and dan back and yang berbasis web.

a. Perancangan Antar muka wisatawan
1. Perancangan form Registrasi Wisatawan

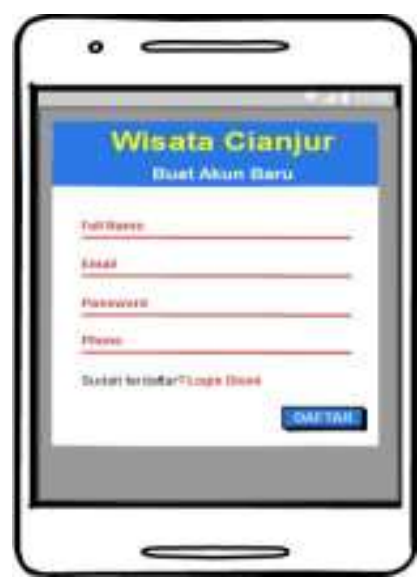

Gambar 5

Halaman Registrasi

Design di atas digunakan oleh wisatawan dalam melakukan registrasi setelah mengunduh aplikasi pada playstore, sebagai member account dari apliasi.

2. Perancangan form login pada sistem

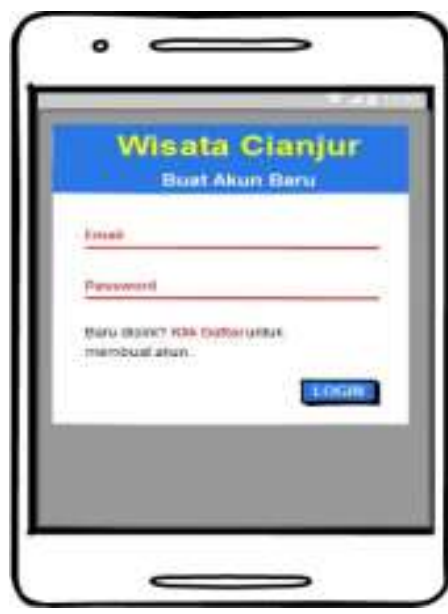

Gambar 6

Halaman Login

Setelah melakukan registrasi maka wisatawan dapat melakukan login untuk masuk ke dalam aplikasi. 
3. Perancangan Form deskripsi objek wisata

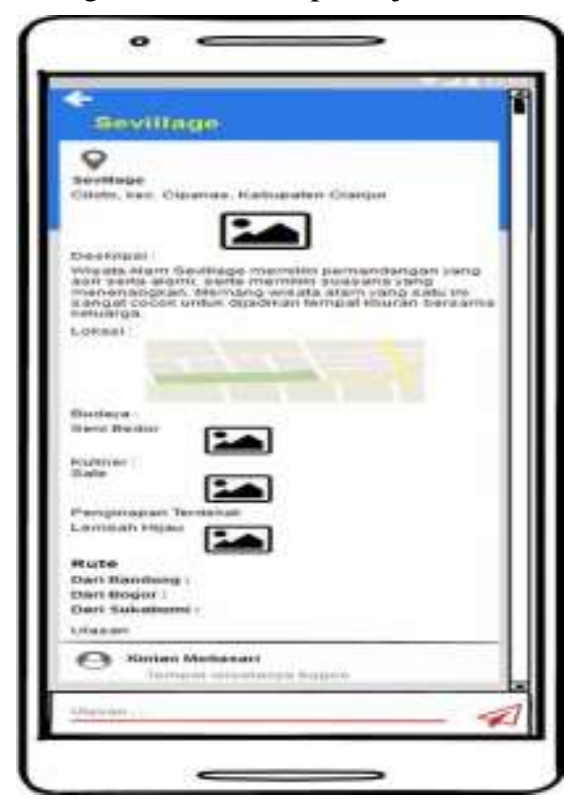

Gambar 7

Halaman Detail Informasi Wisata

Pada design form diatas wisatawan bisa melakukan pencarian wisata yang ada di daerah cianjur dengan jarak tempuh, lokasi hot wisata, kuliner dan penginapan yang ada di lokasi objek wisata tersebut.

4. Perancangan form Profil

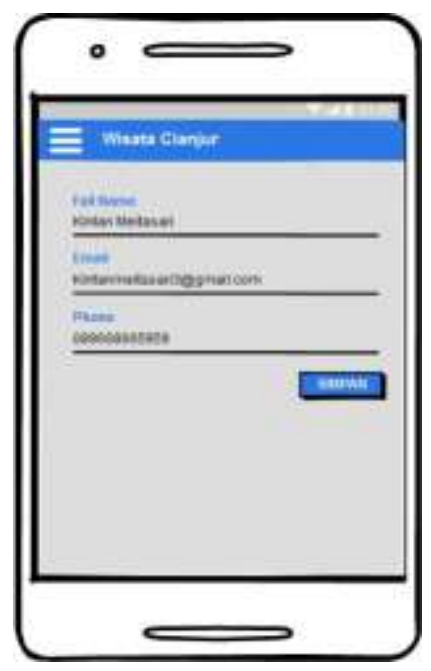

Gambar 8

Halaman Profile
5. Perancangan form Galeri

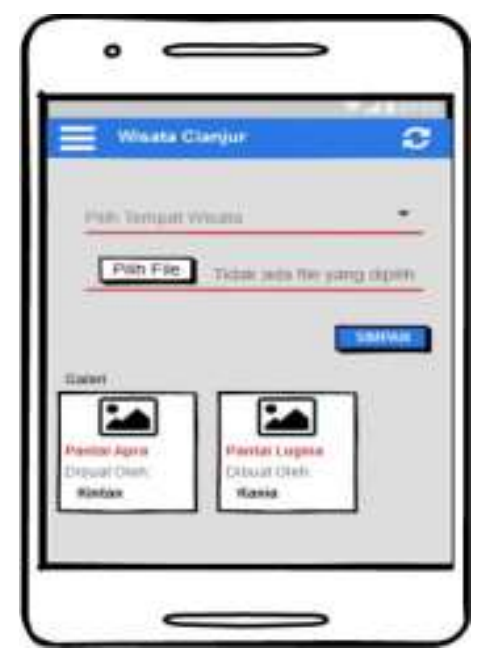

Gambar 9

Halaman Galeri

Pada design form galeri ini wisatwan bisa berbgai photo dan salaing berkomentar bercerita secara online dengan wisatawan lain yang pernah berkunjung.

b. Perancangan Antar muka Pengelola

Pada perancangan antar muka pengelola ini berbasis web base.

1. Perancangan Web form Login

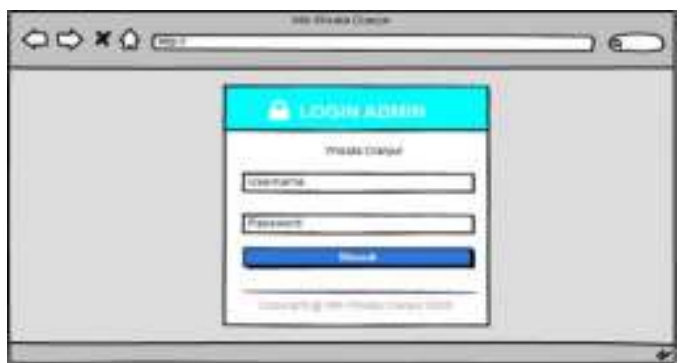

Gambar 10

Halaman Login Staff Pengelola Web

2. Perancangan Web Kelola Objek Wisata

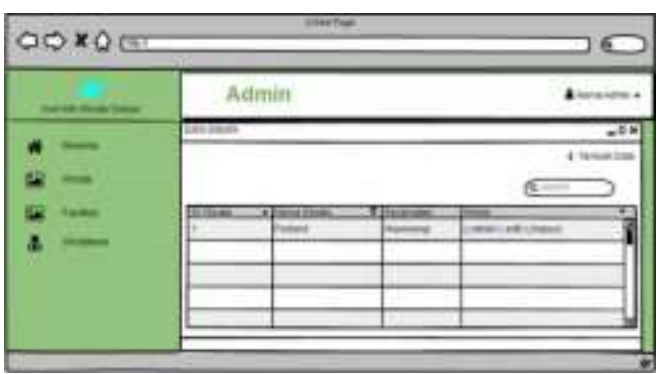

Gambar 11

Halaman Kelola Data Wisata 
3. Perancangan Web kelola fasilitas wisata

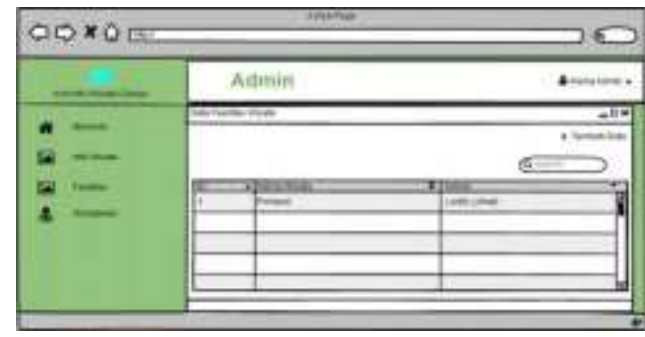

Gambar 12

Halaman Kelola Data fasilitas

4. Perancangan Web data pengelola

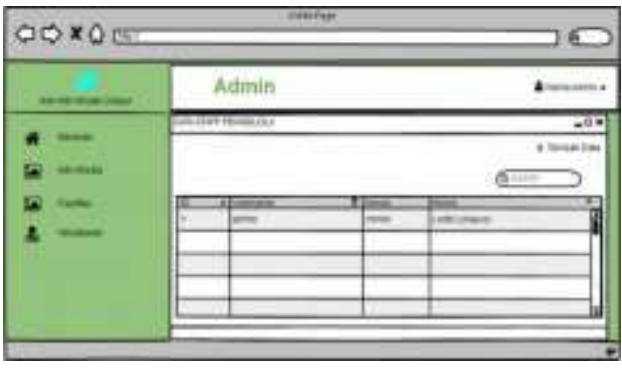

Gambar 13

Halaman Kelola Data Staff

\section{PEMBAHASAN}

Pada Tahap pembahasan ini merupakan proses lanjutan dari hasil penerlitain yang akan di implementasikan. Implementasi merupakan proses representasi dari analisis dan perancangan menjadi suatu aplikasi atau pengkodean program dengan bahasa pemrograman tertentu.

a. Kebutuhan Perangkat Lunak

Spesifikasi dari perangkat keras yang digunakan untuk pembuatan Perancangan Sistem Informasi Deskripsi Pariwisata di Kabupaten Cianjur Berbasis Media Sosial ini sebagai berikut :

1. Sistem Operasi Windows 10 Pro

2. XAMPP

3. MySQL

4. PhoneGap

5. Visual Paradigm

6. Microsoft Word 2016

7. Google Maps API

b. Kebutuhan Perangkat Keras

Spesifikasi perangkat lunak yang digunakan untuk membangun dan mengimplementasikan Perancangan Sistem Informasi Deskripsi objek wisata di Kabupaten Cianjur Berbasis Media Sosial :

\begin{tabular}{|l|l|l|}
\hline No & Perangkat & Spesifikasi \\
\hline 1 & \multicolumn{2}{|l|}{ ProcessorAMD Quad Core A8-7410 2.2 } \\
& & Ghz \\
\hline 2 & Harddisk & 325 GB \\
\hline 3 & Memory & D DR3 8.00 G B RAM \\
\hline 4 & Monitor & 14 Inch \\
\hline 5 & Mouse & Standar \\
\hline 6 & Keyboard & Standar \\
\hline
\end{tabular}

c. Kebutuhan Perangkat Keras dan Perangkat Lunak Pengguna

Kebutuhan perangkat lunak yang digunakan oleh wisatawan untuk menjalankan sistem adalah sebagai berikut:

1. Operating system android minimal Jelly Bean

2. Ukuran layar smartphone 4 s/d 6 Inchi

3. RAM smartphone $2 \mathrm{~GB}$

4. Koneksi Internet atau mobile data yang stabil

d. Implementasi Antarmuka Wisatawan

Pada implementasi sistem antar muka akan di bahasa sama penulis tentang desigsn form yang sudah jadi.

a. Form Registrasi Wisatawan

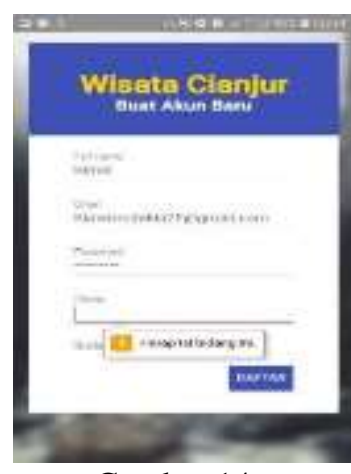

Gambar 14

Form registrasi Wisatawan

b. Form Login Wisatawan

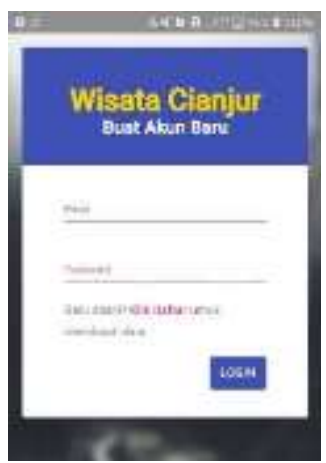

Gambar 15

Implementasi Antarmuka Login Wisatawan

c. Form Informasi Objek Wisata

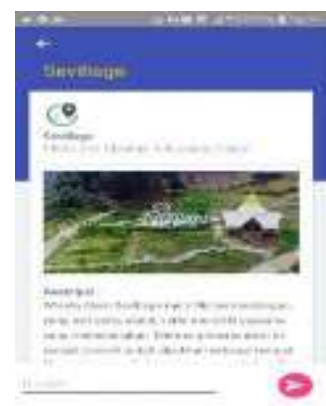

Gambar 16

Implementasi Antarmuka Objek Wisata Cianjur 


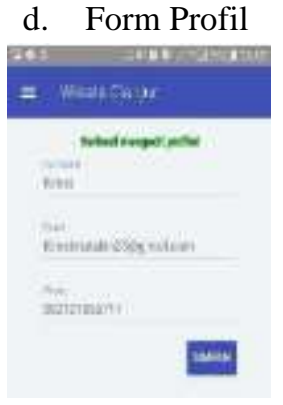

Gambar 17

Implementasi Antarmuka Halaman Profile

e. Form Galery Medsos

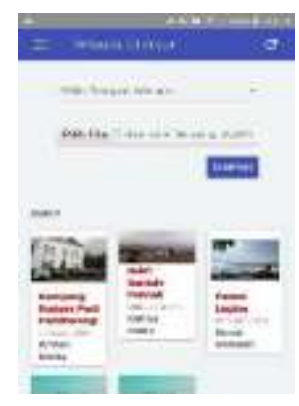

Gambar 18

Implementasi Antarmuka Form Galery Medsos

e. Implementasi Antarmuka Pengelola

Pada impelmentasi antarmuka pengelola ini berbeda dengan perancangan antar muka wisatawan, antarmuka pengelola di rancang berbasis web base

1. Halaman login

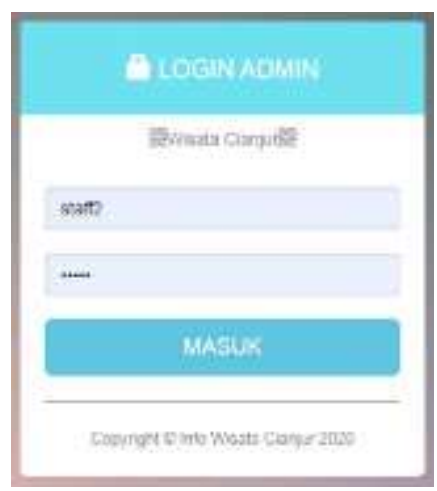

Gambar 19

Implementasi Halaman Login Pengelola
2. Halaman kelola data wisata

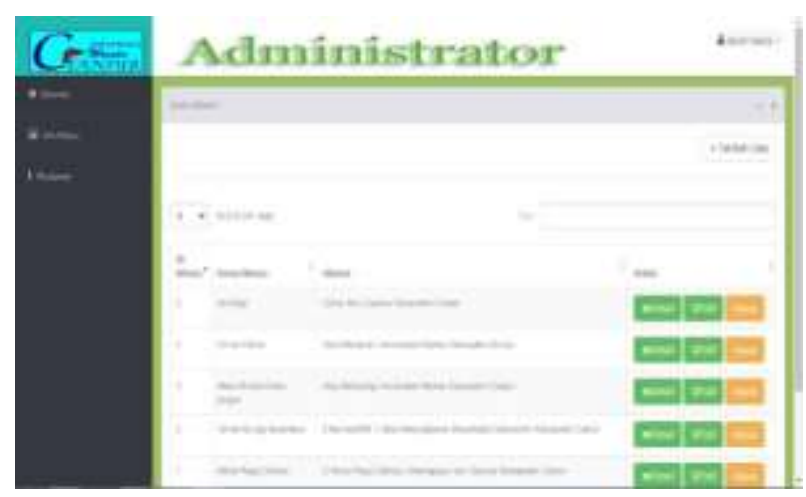

Gambar 20

Implementasi Halaman Kelola Data Wisata

3. Halaman kelola data fasilitas wisata

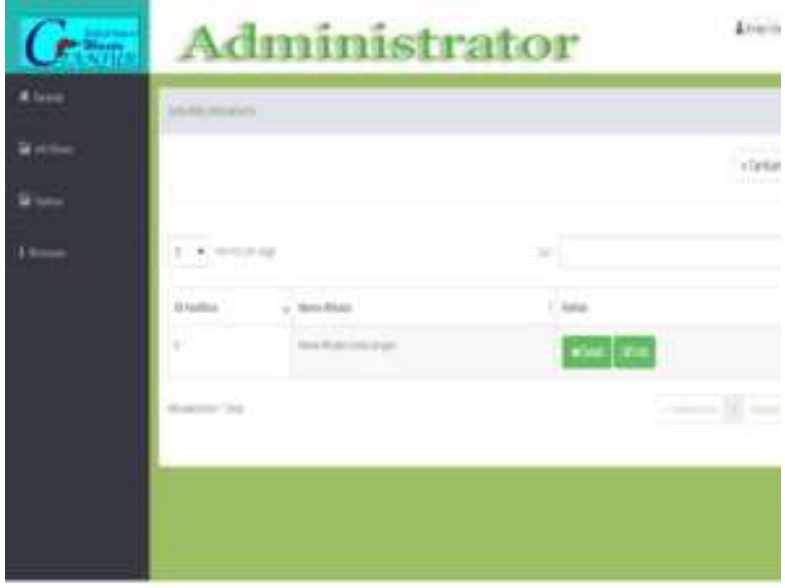

Gambar 21

Implementasi Halaman Kelola Data fasilitas Wisata

4. Halaman kelola data pengeloa

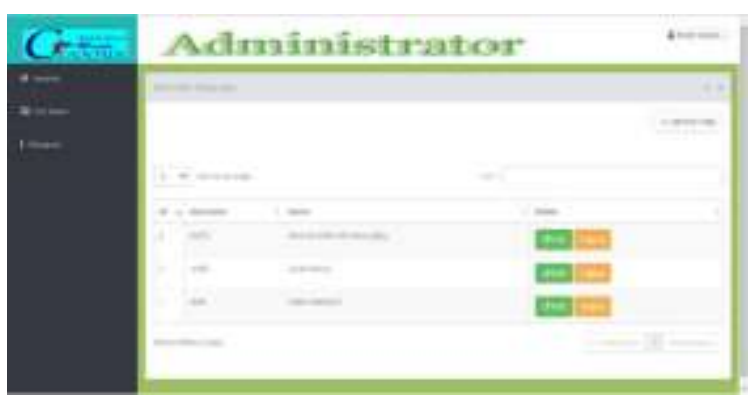

Gambar 22

Implementasi Halaman Kelola data pengelola 
f. Pengujian Black Box

Black box testing adalah pengujian yang dilakukan hanya mengamati hasil eksekusi melalui data uji dan memeriksa fungsional dari perangkat lunak. Pada pengujian ini peneliti akan melakukan pengujian pada bagian tertentu yang di anggap mewakili dari semua implentasi perangkat lunak

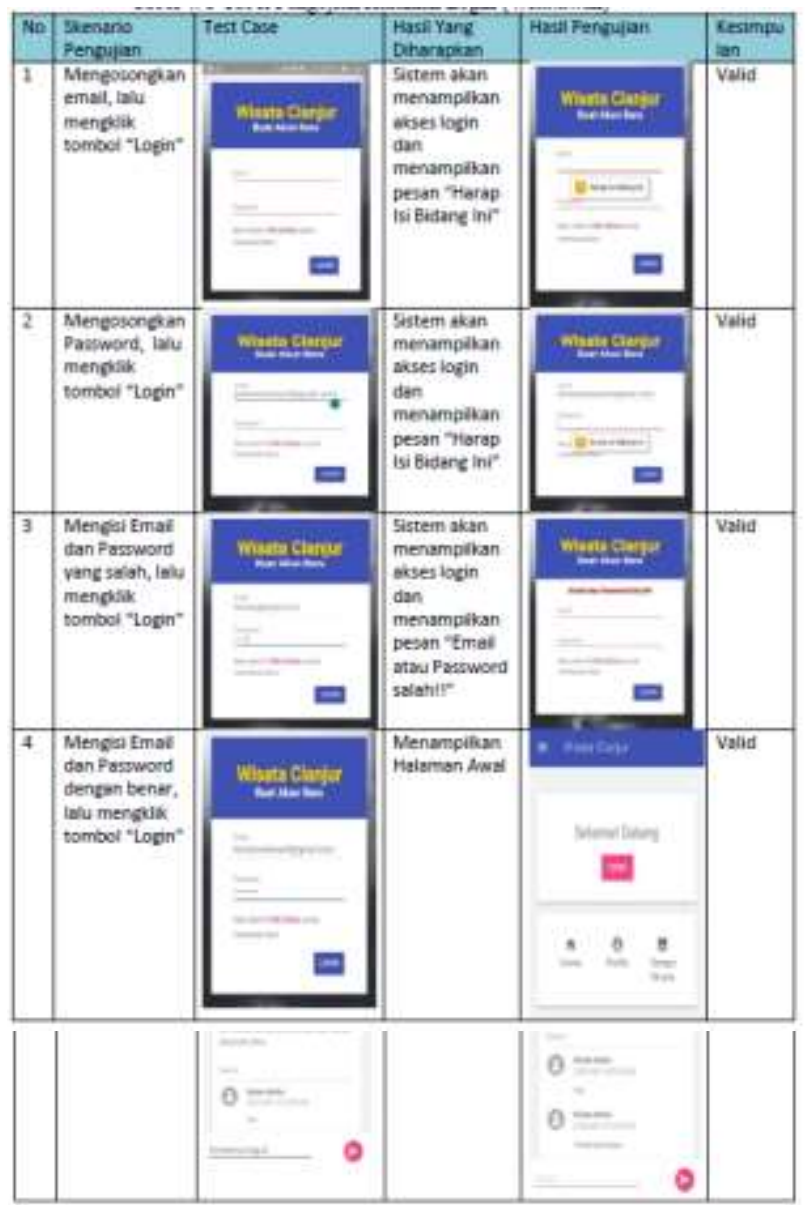

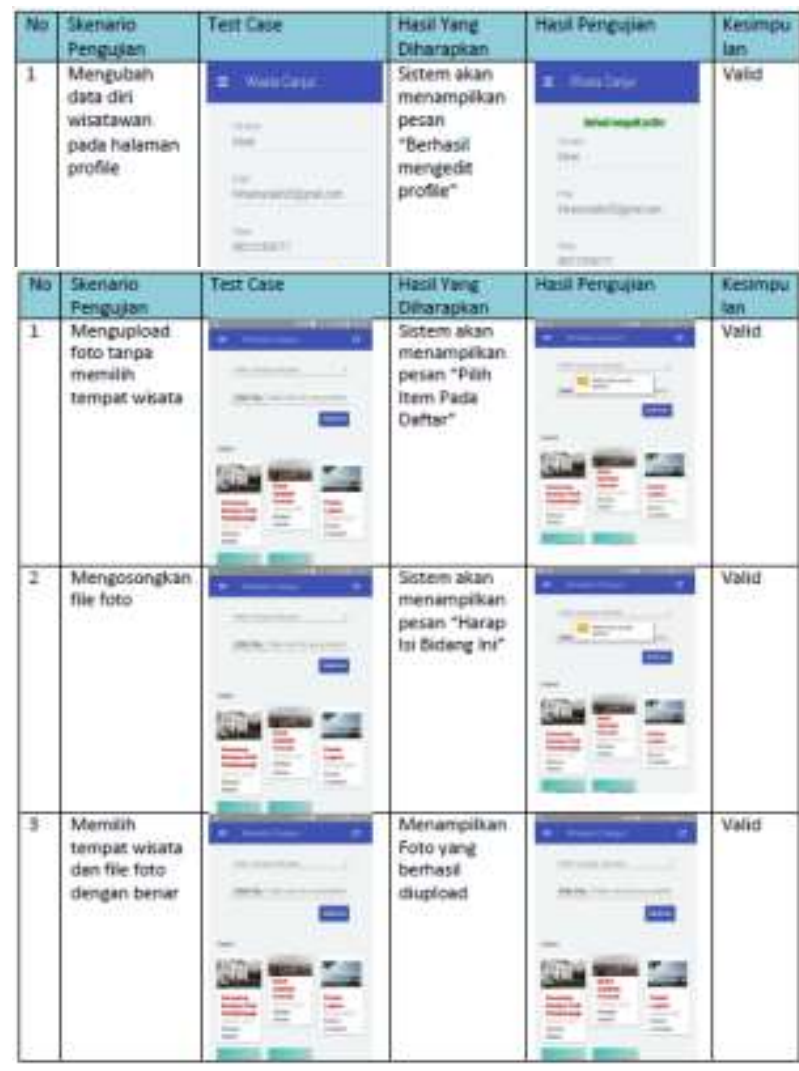

\section{KESIMPULAN}

Berdasarkan hasil analisis, perancangan dan implementasi selama melaksanakan penelitian Tugas Akhir yang berjudul Perancangan Sistem Informasi Deskripsi Pariwisata di Kabupaten Cianjur Berbasis Media Sosial, dapat disimpulkan bahwa:

a. Telah dibangun Aplikasi Info Wisata Cianjur yang dapat membantu Wisatawan lokal maupun luar Cianjur dalam mencari informasi wisata alam di Kabupaten Cianjur.

b. Dapat membantu Wisatawan lokal maupun luar Cianjur dalam mencari informasi Penginapan terdekat dengan wisata alam tersebut.

c. Dapat membantu Wisatawan lokal maupun luar Cianjur dalam mencari informasi kuliner dan budaya khas sekitar daera wisata alam tersebut. 


\section{REFERENSI}

[1]. Arnhold, M., Quade, M., \& Kirch, W. (2014). Mobile applications for diabetics: a systematic review and expert-based usability evaluation considering the special requirements of diabetes patients age 50 years or older. Journal of Medical Internet Research, 16(4), e104.

[2]. Brady, M., \& Loonam, J. (2010). Exploring the use of entity -relationship diagramming as a technique to support grounded theory inquiry. Qualitative Research in Organizations and Management: An International Journal.

[3]. Hardjono, D. (2006). Seri Panduan Lengkap Menguasai Pemrograman Web dengan PHP 5. ANDI Yogyakarta.

[4]. Harrison, R., Flood, D., \& Duce, D. (2013). Usability of mobile applications: literature review and rationale for a new usability model. Journal of Interaction Science, 1(1),

[5]. Hutahaean, J. (2015). Konsep system informasi. Deepublish.

[6]. Jadhav, J. D., Pratiksha, S., Ashwini, S., Sunita, G., \& Kumari, D. (n.d.). Map Application Using Augmented Reality Technology for Smart Phones 